\title{
NCGS like IBS 'type' symptoms is a diagnosis of exclusion
}

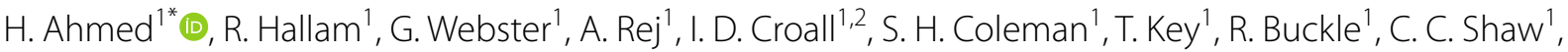 \\ J. Goodwin' ${ }^{1}$ I. Aziz ${ }^{1}$ and D. S. Sanders ${ }^{1}$
}

Keywords: NCGS, IBS, Gluten

\section{Dear Editor,}

We read with great interest the recent article by Moleski et al. [1], discussing symptoms of gluten ingestion in patients with Non-Celiac Gluten Sensitivity (NCGS). Notably, the authors highlight that without an objective marker for NCGS, participants within the study may have had alternative gastrointestinal diagnoses. Very little has been published about investigating patients with NCGS (that self-report symptoms occurring following the ingestion of gluten).

It is important to highlight to readers that patients who present with either self-reported NCGS or irritable bowel syndrome (IBS) 'type' symptoms should be investigated for other causes for their gastrointestinal symptoms. In view of this, we reviewed the case notes of patients with self-reported NCGS $(n=205)$ and with a new presentation of IBS 'type' symptoms $(n=74)$. Patients were divided into two groups, group one consisted of individuals presenting with self-reported NCGS. In contrast, group two consisted of individuals with a new presentation of IBS 'type' symptoms. Individuals were characterised according to demographics, in addition to investigative outcomes.
We found that patients presenting with NCGS and IBS 'type' symptoms were predominantly female, at $84 \%(n=172)$ and $62 \%(n=46)$ respectively. There was no significant difference in the presenting age between patients (NCGS mean age $40.0 \pm 15.7$ years vs IBS mean age $38.4 \pm 14.1$ years; $p=0.56$ ). Following investigation, $11.7 \%(n=24)$ of NCGS and $17.6 \%(n=13)$ of patients with IBS 'type' symptoms were found to have other gastrointestinal diagnosis (Tables 1 and 2). The most common diagnosis for the NCGS group was celiac disease (CD) $(8.8 \%, n=18)$ and by comparison for patients with IBS 'type' symptoms it was bile acid diarrhoea (BAD) $(13.5 \%, n=10)$.

We conclude that the demographics of patients with NCGS and IBS are similar, with a young female presentation. We found a significant minority of these patients have other GI diagnoses. The data supports the recommendation that patients presenting with self-reported NCGS should only be confirmed as having NCGS after excluding other gastrointestinal disorders. We have also demonstrated from our data that a similar approach is required in patients with IBS 'type' symptoms. One strategy that may help would be the utilisation of the Salerno experts' criteria in reaching a firm and positive diagnosis of NCGS

*Correspondence: hamza.ahmed7@nhs.net

1 Academic Unit of Gastroenterology, Royal Hallamshire Hospital,

Sheffield Teaching Hospital NHS Foundation Trust, Sheffield S10 2JF, UK

Full list of author information is available at the end of the article original author(s) and the source, provide a link to the Creative Commons licence, and indicate if changes were made. The images or other third party material in this article are included in the article's Creative Commons licence, unless indicated otherwise in a credit line to the material. If material is not included in the article's Creative Commons licence and your intended use is not permitted by statutory regulation or exceeds the permitted use, you will need to obtain permission directly from the copyright holder. To view a copy of this licence, visit http://creativecommons.org/licenses/by/4.0/. The Creative Commons Public Domain Dedication waiver (http://creativecommons.org/publicdomain/zero/1.0/) applies to the data made available in this article, unless otherwise stated in a credit line to the data. 
Table 1 Breakdown of the diagnosis of patients presenting with self-reported gluten sensitivity

\begin{tabular}{ll}
\hline Final primary diagnosis & $\begin{array}{l}\text { Number } \\
\text { of patients } \\
\text { (\%) }\end{array}$ \\
\hline Non-celiac gluten sensitivity (NCGS) & $181(88.3)$ \\
Celiac disease (CD) & $18(8.8)$ \\
Fructose intolerance & $1(0.5)$ \\
Lactose intolerance & $2(1.0)$ \\
Small intestinal bacterial overgrowth (SIBO) & $3(1.5)$ \\
Total & $205(100.0)$ \\
\hline
\end{tabular}

Table 2 Breakdown of the diagnosis of patients presenting with IBS 'type' symptoms

\begin{tabular}{ll}
\hline Final primary diagnosis & $\begin{array}{l}\text { Number } \\
\text { of patients } \\
\text { (\%) }\end{array}$ \\
\hline Irritable Bowel Syndrome (IBS) & $61(82.4)$ \\
Bile acid diarrhoea (BAD) & $10(13.5)$ \\
Microscopic colitis & $2(2.7)$ \\
Pancreatic exocrine insufficiency (PEI) & $1(1.4)$ \\
Total & $74(100.0)$
\end{tabular}

which would in turn improve the validity of the results published [2]. Whilst this approach may be regarded as cumbersome, it would facilitate comparison of different studies if adopted universally [2]. We fear that until a validated a biomarker of NCGS is discovered, further research in NCGS pathogenesis and triggers may be futile.

\section{Acknowledgements}

N/A

\section{Authors' contributions}

All authors contributed to the letter. The author(s) read and approved the final manuscript.

\section{Authors' information}

N/A

Funding

N/A

\section{Availability of data and materials}

N/A

\section{Declarations}

Ethics approval and consent to participate

Conducted in accordance with ethics approval. Consent to participate N/A

\section{Consent for publication}

N/A

\section{Competing interests}

The authors declare no competing interests.

\section{Author details}

${ }^{1}$ Academic Unit of Gastroenterology, Royal Hallamshire Hospital, Sheffield Teaching Hospital NHS Foundation Trust, Sheffield S10 2JF, UK. ${ }^{2}$ Academic Unit of Radiology, University of Sheffield, Sheffield, UK.

Received: 6 June 2021 Accepted: 30 August 2021

Published online: 08 September 2021

References

1. Moleski S, Shah A, Durney P, Matthews M, Kaushal G, Smith C, et al. Symptoms of gluten ingestion in patients with non-celiac gluten sensitivity: a randomized clinical trial. Nutrition. 2021;81:110944.

2. Catassi C, Elli L, Bonaz B, Bouma G, Carroccio A, Castillejo G, et al. Diagnosis of non-celiac gluten sensitivity (NCGS): the Salerno experts' criteria. Nutrients. 2015;7(6):4966-77.

\section{Publisher's Note}

Springer Nature remains neutral with regard to jurisdictional claims in published maps and institutional affiliations.

\footnotetext{
Ready to submit your research? Choose BMC and benefit from:

- fast, convenient online submission

- thorough peer review by experienced researchers in your field

- rapid publication on acceptance

- support for research data, including large and complex data types

- gold Open Access which fosters wider collaboration and increased citations

- maximum visibility for your research: over $100 \mathrm{M}$ website views per year

At BMC, research is always in progress.

Learn more biomedcentral.com/submissions 